\title{
Localized outbreaks of coral disease on Arabian reefs are linked to extreme temperatures and environmental stressors
}

\author{
Greta Smith Aeby ${ }^{1,2}$ (1) Emily Howells ${ }^{3,4}$ - Thierry Work ${ }^{5}$ - David Abrego ${ }^{6,7}$. \\ Gareth J. Williams $^{8} \cdot$ Lisa M. Wedding $^{9}$ Jamie M. Caldwell $^{1,10} \cdot$ Monica Moritsch $^{11}$. \\ John A. Burt ${ }^{3}$
}

Received: 8 December 2019/Accepted: 29 March 2020/Published online: 20 April 2020

(C) The Author(s) 2020

\begin{abstract}
The Arabian Peninsula borders the hottest reefs in the world, and corals living in these extreme environments can provide insight into the effects of warming on coral health and disease. Here, we examined coral reef health at 17 sites across three regions along the northeastern Arabian Peninsula (Persian Gulf, Strait of Hormuz and Oman Sea) representing a gradient of environmental conditions. The Persian Gulf has extreme seasonal fluctuations in temperature and chronic hypersalinity, whereas the other two regions experience more moderate conditions. Field surveys identified 13 coral diseases including tissue loss diseases of unknown etiology (white syndromes) in Porites, Platygyra, Dipsastraea, Cyphastrea, Acropora and Goniopora; growth anomalies in Porites, Platygyra and Dipsastraea; black band disease in Platygyra, Dipsastraea, Acropora, Echinopora and Pavona; bleached
\end{abstract}

Topic Editor Bernhard Michael Riegl

Electronic supplementary material The online version of this article (https://doi.org/10.1007/s00338-020-01928-4) contains supplementary material, which is available to authorized users.

Greta Smith Aeby

greta@hawaii.edu

1 Hawaii Institute of Marine Biology, University of Hawaii at Manoa, Honolulu, HI, USA

2 Department of Biological and Environmental Sciences, Qatar University, Doha, Qatar

3 Center for Genomics and Systems Biology, New York University Abu Dhabi, Abu Dhabi, United Arab Emirates

4 School of Earth, Atmospheric and Life Sciences, University of Wollongong, Wollongong, NSW, Australia

5 US Geological Survey, Wildlife Health Center, Honolulu Field Station, Honolulu, HI, USA patches in Porites and Goniopora and a disease unique to this region, yellow-banded tissue loss in Porites. The most widespread diseases were Platygyra growth anomalies (52.9\% of all surveys), Acropora white syndrome (47.1\%) and Porites bleached patches (35.3\%). We found a number of diseases not yet reported in this region and found differential disease susceptibility among coral taxa. Disease prevalence was higher on reefs within the Persian Gulf (avg. 2.05\%) as compared to reefs within the Strait of Hormuz $(0.46 \%)$ or Oman Sea $(0.25 \%)$. A high number of localized disease outbreaks ( 8 of 17 sites) were found, especially within the Persian Gulf (5 of 8 sites). Across all regions, the majority of variation in disease prevalence $(82.2 \%)$ was associated with the extreme temperature range experienced by these corals combined with measures of organic pollution and proximity to shore. Thermal stress is known to drive a number of coral diseases, and thus, this region provides a platform to study disease at the edge of corals' thermal range.

6 Department of Natural Science and Public Health, Zayed University, Abu Dhabi, United Arab Emirates

7 National Marine Science Centre, Southern Cross University, Coffs Harbour, NSW, Australia

8 School of Ocean Sciences, Bangor University, Anglesey LL59 5AB, UK

9 School of Geography and the Environment, University of Oxford, South Parks Road, Oxford OX1 3QY, UK

10 ARC Centre of Excellence for Coral Reef Studies, James Cook University, Townsville, Australia

11 University of California Santa Cruz, Santa Cruz, CA, USA 
Keywords Arabian Peninsula - Coral disease · Disease outbreaks · Environmental drivers

\section{Introduction}

Coral reefs are diverse ecosystems that directly support numerous human populations providing valuable sources of dietary protein and income from fisheries and tourism (Hicks et al. 2019). Unfortunately, the world's coral reefs are in severe decline (Pandolfi et al. 2003, 2011) with an estimated $50 \%$ decline in coral cover from the Indo-Pacific (Bruno and Selig 2007; Death et al. 2012) and a $40 \%$ loss from Caribbean reefs (Gardner et al. 2003; Jackson et al. 2014). Coral reefs are frequently situated along coastlines and are subject to increasing interconnections of human populations and their associated impacts (Williams et al. 2019). Overfishing which removes critical herbivores and land-based pollution with resultant sedimentation, excess nutrients and other pollutants are cited as major local stressors contributing heavily to coral decline (Pandolfi 2003; Hughes et al. 2010). Compounding these threats are increases in sea surface temperatures, changing weather patterns and ocean acidification associated with climate change (Pandolfi et al. 2011; Hughes et al. 2017). Coral disease has been linked to various stressors, including temperature stress, anthropogenic exploitation and pollution (Harvell et al. 2007), and disease outbreaks have occurred in numerous regions (Aeby 2005; Williams and Miller 2005; Williams et al. 2011a; Aeby et al. 2016; Precht et al. 2016). Despite this importance, we are just beginning to understand the ecology and pathogenesis of coral diseases. Numerous questions remain about the causative agents of coral diseases, their prevalence, epidemiology and ecological impacts. While coral disease prevalence has been quantified in many regions across the Indo-Pacific (Willis et al. 2004; Aeby et al. 2008, 2011a, 2015; Haapkylä et al. 2009; Vargas-Ángel 2009; Williams et al. 2011b), we know little about the levels and types of coral disease on reefs in many other regions, including around the Arabian Peninsula (Riegl et al. 2012).

The Persian/Arabian Gulf (hereafter called the Persian Gulf) and Arabian Sea host fringing and patch reefs with over 25 coral genera documented (Coles 2003). These coral species, typical of Indo-Pacific fauna, represent a hardy subset of corals that are able to exist under demanding environmental conditions such as extreme temperature and salinity fluctuations (Riegl et al. 2012). These coral reefs are now under constant threat from multiple human impacts including coastal construction, dredging activity and effluent discharge from seawater desalinization plants
(Sheppard et al. 2010; Burt et al. 2014) and, recently, disease (Coles 1994; Riegl 2002; Riegl et al. 2012).

The first step in understanding threats from disease is to develop baseline information on the types, distribution and prevalence of coral diseases on reefs. Here, we conducted baseline coral disease surveys, along patch and fringing reefs, of the northeastern Arabian Peninsula including within the Persian Gulf, Strait of Hormuz and Oman Sea. These three regions represent a gradient of environmental conditions presenting a natural experiment to examine the effect of stressors on coral health. The Persian Gulf is a semi-enclosed marginal sea, separated from the Indian Ocean by the narrow Strait of Hormuz (Sheppard 1993). Its shallow depth and restricted water exchange with the wider Indian Ocean result in large seasonal fluctuations in ocean temperatures, $15{ }^{\circ} \mathrm{C}-36{ }^{\circ} \mathrm{C}$ (John et al. 1990) and chronic hypersalinity (> 40 ppt) (Vaughan and Al-Mansoori 2019). These extremes in temperature and salinity create stressful conditions that control the distribution and diversity of coral reef species (Bauman et al. 2013). In contrast, the Strait of Hormuz and Oman Sea have wider connections with the larger Indian Ocean, and so, coral reefs exist in less extreme environments with temperatures ranging from 23 to $30{ }^{\circ} \mathrm{C}$ although there are regional exceptions associated with seasonal monsoons and upwelling events (Claereboudt 2019) and salinities averaging 37 ppt (Pous et al. 2004).

The aim of our study was to determine the types and prevalence of coral diseases on coral reefs in the southern Persian Gulf, Strait of Hormuz and Oman Sea. We document taxonomic differences in disease susceptibility and explore environmental drivers of regional variation in disease prevalence. Such information will provide critical data that are essential to help guide reef management efforts in a region where such data are currently deficient. Baseline disease data give managers the capacity to track the health of their reefs through time and can focus monitoring efforts on sites or corals that are more prone to disease.

\section{Materials and methods}

\section{Disease surveys}

Coral community structure and disease prevalence were recorded along the northeastern Arabian Peninsula at 17 sites having different environmental conditions. Surveys were conducted at eight sites in the Persian Gulf, five sites in the Strait of Hormuz and four sites in Oman Sea, which represent a gradient of salinity and temperature extremes and potential human impacts (Fig. 1; Supplementary Table 1). Additionally, reefs closer to shore, within these 
regions, may be more strongly impacted by anthropogenic activities such as coastline modification and dredging, as well as discharge from desalinization, wastewater treatment and industrial facilities (Sheppard et al. 2010). At each site, teams of divers surveyed two replicate $25 \mathrm{~m}$ belt transects recording the diversity and abundance of coral genera and the prevalence of coral disease. Corals were identified to the genus level along $25 \times 1 \mathrm{~m}$ belts and substrate characteristics were documented by line-intercept method with the substratum underlying the tape measure recorded at $50-\mathrm{cm}$ intervals.

Coral lesions were assessed along wider $25 \times 2 \mathrm{~m}$ belts. Gross lesions were classified into three broad categories including tissue loss, discoloration and growth anomaly, and nomenclature for lesions was based on the host genus affected and the lesion type (e.g., Porites growth anomaly; Work and Aeby 2006). Tissue loss lesions were further classified as known cause (e.g., predation) or unknown cause (e.g., infectious or non-infectious disease processes) based on the lesion size, shape, presence of predators, knowledge of what common predation marks look like and evidence of lesion progression based on degree of algal colonization onto the bare coral skeleton. Only lesions that were thought to be due to disease processes were included in the analyses. Paired normal and lesion tissues were sampled for histopathologic examination and examined for the presence of organisms that could be contributing to gross lesions (Work et al. 2012). Tissue loss lesions not found associated with obvious microorganisms were termed 'white syndrome' indicating a tissue loss disease of unknown etiology. If ciliates or cyanobacteria were found microscopically invading coral tissue in the lesion, then they were termed ciliate or cyanobacterial infections.

\section{Geospatial Environmental Predictors}

To examine the association between disease prevalence and environmental variables, survey data were combined with spatially explicit environmental data to develop statistical models (Williams et al. 2010; Aeby et al. 2011a). To model different anthropogenic stressors on coral reefs, we used existing 2013 data for three metrics of human impacts on marine environments from the Ocean Health Index (OHI) (Halpern et al. 2015): coastal human population, organic pollution and ocean pollution (Table 1, Supplementary Table 1). The OHI creates a spatially explicit stress index (1 km resolution) for each metric of ocean impact by synthesizing remotely sensed data. The impact of human population was based on satellite estimates of human population size within $10 \mathrm{~km}$ of each coast-adjacent ocean grid cell. Organic pollution impact was based on plume models of pesticide use and land use. Ocean pollution impact was derived from pollutant plumes originating in ports and number of shipping tracks from Automatic Identification System and Volunteer Observing System data. For each of these metrics, environmental predictor values at each georeferenced survey location were found using ArcGIS 10.5. Proximity to shore was estimated by measuring the Euclidean distance $(\mathrm{m})$ of each survey site from the coastline using the Near function in ArcGIS. Long-term temperature-based metrics using satellitederived sea surface temperature (SST) were calculated, and the metric chosen to represent temperature stress was temperature range for each site. This metric was calculated by taking the mean of the annual temperature range each year over a 5-yr time period leading up to the survey date. The annual values from $5 \mathrm{~km}$ daily temperature values were calculated from the National Oceanic and Atmospheric Administration (NOAA) Coral Reef Watch
Fig. 1 Map of the Arabian Peninsula showing sites surveyed for coral diseases in the southern Persian Gulf, Strait of Hormuz and the Gulf of Oman. Site GPS coordinates and depths are provided in Supplementary Table S1

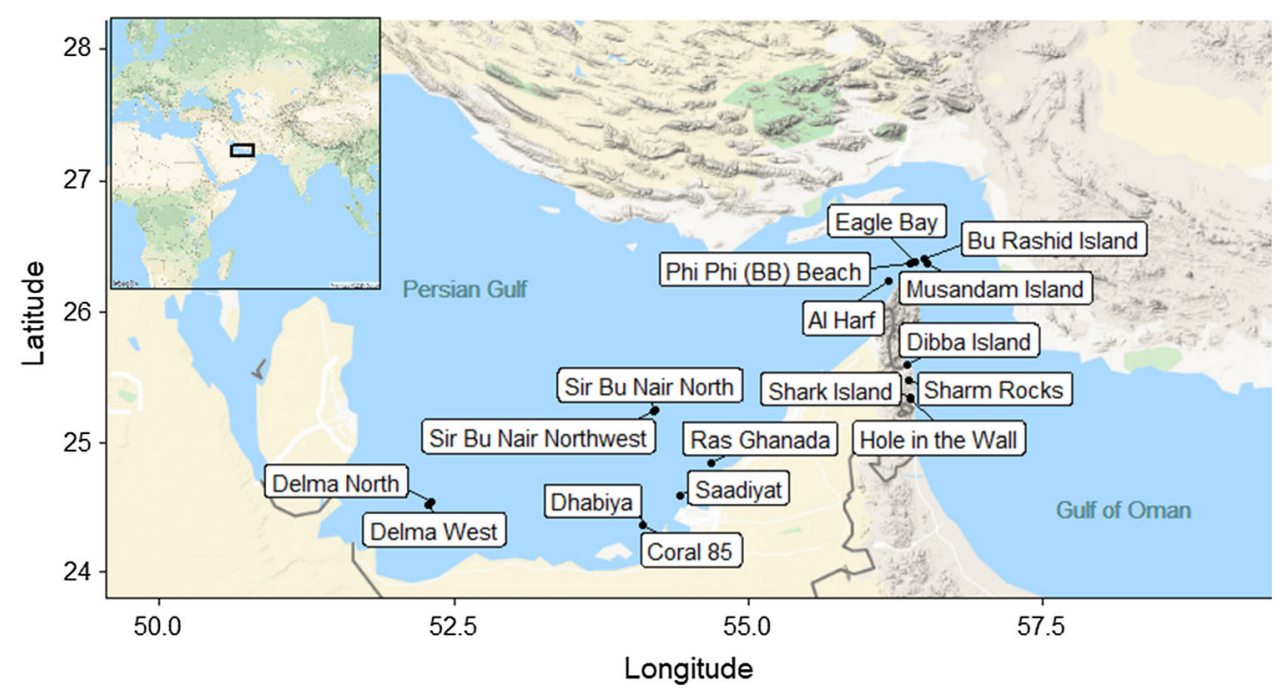


Table 1 Predictor variables used to model environmental drivers of coral disease along the Arabian Peninsula

\begin{tabular}{|c|c|c|c|c|c|}
\hline Variable & Code & Description and units & Min & Max & Source \\
\hline Depth & Depth & Meters & 3.05 & 6.7 & Reef survey \\
\hline Coral cover & Coral cover & $\%$ cover & 20 & 83 & Reef survey \\
\hline $\begin{array}{l}\text { Degree heating } \\
\text { weeks }\end{array}$ & DHW201608 & $\begin{array}{l}\text { Max degree heating weeks accumulated } \\
\text { June to August in } 2016\end{array}$ & 0 & 1.23 & $\begin{array}{l}\text { NOAA coral reef watch monthly } \\
\text { composites } \\
\text { (coralreefwatch.noaa.gov/satellite/ } \\
\text { index.php) }\end{array}$ \\
\hline $\begin{array}{l}\text { Annual Sea surface } \\
\text { temperature range }\end{array}$ & $\begin{array}{l}\text { mean_annual_ } \\
\text { SST_range }\end{array}$ & $\begin{array}{l}5 \text { yr mean SST temperature range }\left({ }^{\circ} \mathrm{C}\right) \text {. } \\
\text { Annual values were derived from } 5 \mathrm{~km} \\
\text { daily temperature values }\end{array}$ & 10.55 & 15.44 & $\begin{array}{l}\text { NOAA Coral Reef Watch 'CoralTemp' } \\
\text { SST Vers. } 3.1 \text { (https://coralreefwatch. } \\
\text { noaa.gov/product/5km/index_5km_ } \\
\text { sst.php) }\end{array}$ \\
\hline $\begin{array}{l}\text { Human numbers } \\
\text { within } 10 \mathrm{~km}\end{array}$ & pop-OHI & $\begin{array}{l}\text { Estimate of population within } 10 \mathrm{~km} \text { of } \\
\text { each ocean grid cell adjacent to land }\end{array}$ & 0 & 44,304 & $\begin{array}{l}\text { Halpern et al. (2015) Ocean Health } \\
\text { Index knb.ecoinformatics.org/\#view/ } \\
\text { https://doi.org/10.5063/f1s180fs }\end{array}$ \\
\hline Organic pollution & Organic & $\begin{array}{l}\text { Organic pollution modeled from per- } \\
\text { country pesticide use, land cover, } \\
\text { watershed data, and diffusive plume } \\
\text { model } 2007-2010\end{array}$ & 0 & 0.36 & $\begin{array}{l}\text { Halpern et al. (2015) Ocean Health } \\
\text { Index knb.ecoinformatics.org/\#view/ } \\
\text { https://doi.org/10.5063/f1s180fs }\end{array}$ \\
\hline Ocean pollution & ocean_poll & $\begin{array}{l}\text { Modeled plumes from ports combined } \\
\text { with shipping data for } 2011\end{array}$ & 0 & 1.43 & $\begin{array}{l}\text { Halpern et al. (2015) Ocean Health } \\
\text { Index knb.ecoinformatics.org/ } \\
\text { \#view/doi: } 10.5063 / \mathrm{F} 1 \mathrm{~S} 180 \mathrm{FS}\end{array}$ \\
\hline Distance to shore & Near_Dist & Distance $(\mathrm{m})$ to nearest coastline segment & 37.6 & $70,216.90$ & $\begin{array}{l}\text { Open Street Map country coastlines } \\
\text { (mapcruzin.com/free-world-country- } \\
\text { arcgis-maps-shapefiles.htm) }\end{array}$ \\
\hline
\end{tabular}

'CoralTemp' SST version 3.1 (https://coralreefwatch.noaa. gov/product $/ 5 \mathrm{~km} /$ index_5km_sst.php). Maximum degree heating week (DHW) values were used and derived from monthly maximum composites of NOAA Coral Reef Watch DHWs, a measure of cumulative heat stress over a 12-week rolling window and measured at $5 \mathrm{~km}$ spatial resolution; the monthly composites were from June, July and August 2016 (Table 1).

\section{Statistical analyses}

\section{Quantifying disease prevalence and coral composition (univariate analyses)}

Time constraints underwater prevented enumeration of all coral colonies within the wider belt transects surveyed for disease. Hence, the prevalence of lesions was calculated by extrapolating colony counts within the $25 \times 1 \mathrm{~m}$ transect to the wider $25 \times 2 \mathrm{~m}$ disease survey area and by using this as the denominator of prevalence calculations (e.g., (number of colonies with lesions/total number of estimated colonies $) \times 100)$. The frequency of disease occurrence (FOC) was defined as the number of sites having corals with lesions divided by total number of sites surveyed. FOC reflects the spatial distribution of diseases on reefs. Data were not normally distributed, even with transformation, so nonparametric analyses were used. For each ocean region, a Chi square test for equality of distributions examined differences in the distribution of the number of diseased versus healthy colonies among the scleractinian genera affected by disease. All calculations for disease prevalence or FOC were by coral genera (e.g., prevalence of Porites yellow-banded tissue loss disease was calculated as the total number of infected Porites colonies divided by the estimated number of Porites colonies surveyed, multiplied by 100). A Kruskal-Wallis test examined regional differences in coral cover, number of coral genera and colony densities. Nonparametric statistics were performed using JMP Pro 13 statistical software (SAS Institute Inc., Buckinghamshire, UK).

\section{Examining coral and disease assemblage patterns (multivariate analyses)}

Differences in coral communities and disease assemblages among regions were investigated using multivariate community analyses. We tested for differences in coral host community patterns (proportional abundance of coral genera) and coral disease assemblage patterns (disease prevalence) for the fixed factor 'Region' (three levels: Persian Gulf, Strait of Hormuz and Oman Sea) using permutational multivariate analysis of variance (PERMANOVA) (Anderson 2001). The raw percentage coral cover values were used to construct a Bray-Curtis similarity 
matrix, as the values were directly comparable across regions, and models were based on 9999 random permutations of the raw data under a reduced model and type III (partial) sums of squares. For the disease assemblage data, we used a zero-adjusted Bray-Curtis similarity matrix due to the relatively large number of zero prevalence records for some of the diseases within the sites (Clarke et al. 2006). Three sites that contained non-true zero prevalence values (i.e., the particular coral host was not recorded at that site) or denuded (all zero) disease prevalence values were removed from the analysis (Musandam Island, Delma West, Delma north), leaving 14 sites in total. Where the global model was significant, we calculated PERMANOVA pairwise comparisons between factor levels (i.e., regions) and visualized the results using a constrained canonical analysis of principal coordinates (CAP) (Anderson and Willis 2003). To identify the core coral genera and disease types driving differences among factor levels within the CAP plot, we calculated Pearson's correlation values of the CAP ordination axes with the original coral and disease variables. Coral genera and disease types with strong correlations (defined as $\geq 0.6$ in this study) were then overlaid as a bi-plot to visualize the direction and strength of the correlation.

\section{Modeling disease-environment associations (multivariate analyses)}

To identify correlations between overall disease prevalence (univariate response) and disease assemblages (multivariate response) with environmental and human drivers that could affect disease processes, we used a permutational distance-based multiple regression technique (DISTLM) (McArdle and Anderson 2001). DISTLM carries out a partitioning of variation in a data set described by a resemblance matrix according to a regression (or multiple regression) model. Predictor variables can be categorical or continuous and the technique makes no prior assumptions about the nature of the response variable distribution, meaning that normality does not have to be satisfied. Predictor variables included coral cover, depth, measures of potential heat stress (degree heating weeks, SST range) and potential human stress (nearby human population size, organic pollution, ocean pollution, proximity to shore) (Table 1). The model was based on 9999 random permutations of the raw data and a Euclidean distance matrix. The predictors were first investigated for collinearity by calculating their pairwise Pearson's correlation values ( $r=<0.6$ in all cases), and therefore, all eight predictors were included in the model fitting exercise. During the model fitting process, all possible candidate models (i.e., all possible unique combinations of the predictors) were fitted. Importantly, when more than one predictor was included, its ability to capture variation in the response variable was conditional on the performance of other predictors included in the model. The final optimal model (balancing performance against model complexity) was identified using Akaike's information criterion (Akaike 1973) with a second-order bias correction applied (AICc) to help account for the relatively low sample sizes (Hurvich and Tsai 1989; Burnham and Anderson 2004). This was chosen as the method to identify the most parsimonious model as it adds a 'penalty' for increases in the number of predictor variables. We report the top four models for both response variables (overall disease prevalence and disease assemblage structure) to highlight the change in AICc values with changing model complexity.

\section{Results}

\section{Coral reef characteristics and coral community structure}

Across the 17 sites we surveyed along the Arabian Peninsula, overall average live coral cover was 51.2\% (range $=13-83 \%)$ and average macroalgae cover was $0.1 \%$ (range $=0-2 \%$ ). No significant differences among regions were found for colony densities (Kruskal-Wallis, $X^{2}=0.2, \mathrm{df}=2, p=0.89$ ) or coral cover (Kruskal-Wallis, $X^{2}=5.3, \mathrm{df}=2, p=0.07$ ), but the number of coral genera differed significantly among regions (Kruskal-Wallis, $X^{2}=8.8, \mathrm{df}=2, p=0.01$ ) with sites in the Persian Gulf having the lowest number of coral genera compared to sites within the Strait of Hormuz or Oman Sea (Table 2). We identified 25 coral genera within transects (Table 3) and overall (all surveys combined) Porites was the most common coral genus (avg. $=32.8 \%$ of the coral community), followed by Acropora (avg. = 14.9\%), Faviidae (Favites and Dipsastraea) (avg. = 9.7\%), Platygyra $($ avg. $=9.6 \%)$ and Montipora (avg. $=7.6 \%$ ). Coral community structure was significantly different among regions (PERMAVOVA, pseudo- $F_{2,16}=2.88, p=0.006$ ) and was mainly driven by a higher abundance of Cyphastrea at sites within the Persian Gulf compared to a higher abundance of several genera at sites within the Strait of Hormuz (Oxypora, Stylophora, Montipora, Echinopora, Pocillopora, Pavona) and higher abundances of Favites and Leptastrea at sites within the Oman Sea (Fig. 2).

\section{Types of diseases, occurrence and disease assemblage patterns among regions}

Across the northeastern Arabian Peninsula, we found 13 coral diseases. These included tissue loss diseases of unknown etiology (white syndromes) in Porites, Platygyra, 
Table 2 Comparison of substrate characteristics among regions surveyed in 2016

\begin{tabular}{lllr}
\hline Region & $\begin{array}{l}\text { Avg. number } \\
\text { colonies } / \mathrm{m}^{\wedge} 2\end{array}$ & $\begin{array}{l}\text { Avg. coral } \\
\text { cover }(\%)\end{array}$ & $\begin{array}{l}\text { Avg. number } \\
\text { coral genera }\end{array}$ \\
\hline Persian gulf & $20.5(4.9)$ & $41.2(6.4)$ & $8.6(1.2)$ \\
Strait of Hormuz & $14.7(2.1)$ & $64.2(5.0)$ & $15.6(2.1)$ \\
Oman sea & $15.8(2.7)$ & $55.1(11.1)$ & $14.0(1.7)$ \\
\hline
\end{tabular}

Data reflect mean and standard error (parentheses). Eight sites were surveyed in the Persian Gulf, 5 sites in the Strait of Hormuz and 4 sites in the Oman Sea
Table 3 Coral community composition of three regions surveyed in August, 2016

\begin{tabular}{|c|c|c|c|}
\hline Coral genera & $\begin{array}{l}\text { Persian } \\
\text { gulf }\end{array}$ & $\begin{array}{l}\text { Strait of } \\
\text { hormuz }\end{array}$ & $\begin{array}{l}\text { Oman } \\
\text { sea }\end{array}$ \\
\hline Acanthastrea & 0.07 & 0.17 & 0.63 \\
\hline Acropora & 15.82 & 13.72 & 14.34 \\
\hline Alveopora & 0.00 & 0.03 & 0.00 \\
\hline Anomastrea & 0.01 & 0.00 & 0.08 \\
\hline Coscinarea & 0.38 & 0.00 & 0.27 \\
\hline Cyphastrea & 13.02 & 2.12 & 2.49 \\
\hline Dipsastrea & 9.71 & 0.33 & 14.17 \\
\hline Echinophyllia & 0.00 & 0.58 & 0.00 \\
\hline Echinopora & 0.00 & 0.84 & 0.00 \\
\hline Faviidae & 0.79 & 0.43 & 4.95 \\
\hline Goniopora & 0.00 & 0.39 & 2.66 \\
\hline Hydnophora & 0.00 & 0.21 & 1.63 \\
\hline Leptastrea & 0.04 & 0.47 & 3.90 \\
\hline Montipora & 0.00 & 25.34 & 0.45 \\
\hline Oxypora & 0.00 & 0.29 & 0.00 \\
\hline Pavona & 0.02 & 1.32 & 2.02 \\
\hline Platygyra & 12.71 & 5.05 & 9.22 \\
\hline Plesiastrea & 0.33 & 0.00 & 0.09 \\
\hline Pocillopora & 0.00 & 10.52 & 8.45 \\
\hline Porites & 41.96 & 19.39 & 31.19 \\
\hline Psammacora & 1.40 & 0.43 & 2.85 \\
\hline Siderastrea & 1.07 & 0.08 & 0.47 \\
\hline Stylophora & 2.21 & 8.69 & 0.04 \\
\hline Symphyllia & 0.04 & 0.44 & 0.11 \\
\hline Turbinaria & 0.43 & 0.02 & 0.00 \\
\hline Palythoa & 0.00 & 1.37 & 0.00 \\
\hline Soft corals & 0.00 & 0.86 & 0.00 \\
\hline
\end{tabular}

Eight sites were surveyed in the Persian Gulf, 5 sites in the Strait of Hormuz and 4 sites in the Oman Sea. Data are from colony counts within belt transects and reflect the average proportion $(\%)$ of the coral community represented by each coral taxa. Faviidae includes Favites and Dipsastraea which are difficult to distinguish in the field. The three most common coral genera for each region are in bold

Dipsastraea, Cyphastrea, Acropora and Goniopora; growth anomalies in Porites, Platygyra and Dipsastraea (formerly Favia); black band disease (BBD) in Platygyra, Dipsastraea, Acropora, Echinopora and Pavona; bleached patches in Porites and Goniopora and yellow-banded tissue loss disease in Porites (Figs. 3, 4). Disease prevalence among sites ranged from 0 to $4.6 \%$ with sites within the Persian Gulf having the highest average prevalence compared to the other two regions (Kruskal-Wallis, $X^{2}=6.1$, $\mathrm{df}=2, \quad p=0.048) \quad$ (Fig. 5). Frequency of occurrence (FOC) differed among diseases and regions (Table 4) with the three most widespread diseases, which were found in all regions, being Platygyra growth anomalies found at $52.9 \%$ of the sites (all regions combined), Acropora white syndrome (47.1\% of the sites) and Porites bleached patches (35.3\% of the sites). Prevalence differed among diseases and regions (Table 5) with the highest average disease prevalence being Echinopora BBD (2.8\%) within the Strait of Hormuz, followed by Acropora white syndrome in the Persian Gulf (2.5\%). Disease assemblages differed significantly between regions (PERMANOVA, pseudo$\left.F_{2,13}=3.1, P=0.004\right)$, with sites in the southern Persian Gulf having significantly different disease assemblages than sites in the Strait of Hormuz $(t=1.6, P=0.018)$ and Oman Sea $(t=2.1, P=0.004)$, primarily driven by all types of disease being elevated in the Persian Gulf as compared to the other two regions.

Lacking any historical information on normal disease levels in these regions, we defined a site as having a localized disease outbreak if prevalence was higher than the highest average regional prevalence we found, which was within the Persian Gulf $(2.1 \%)$. Based upon this criterium, we identified eight of 17 sites that had localized outbreaks of a specific disease with prevalence ranging from 2.3 to $21.1 \%$. The Persian Gulf had the highest number of sites with outbreaks (5 of 8 sites) which included an outbreak of Porites yellow-banded tissue loss (prevalence $=6.9 \%$ ) at Saadiyat, Platygyra white syndrome (prevalence $=10.2 \%$ ) at Ras Ghanada and three sites (Coral 85, Sir Bu Nair North, Sir Bu Nair Northwest) with outbreaks of Acropora white syndrome: prevalence $=2.3 \%, 6.6 \%$ and $6.8 \%$. Two sites in the Strait of Hormuz had BBD outbreaks, Eagle Bay had 3.9\% BBD prevalence on Echinopora and Abu Rasheed Island had 7.1\% BBD prevalence on Echinopora and 3.3\% BBD prevalence on Pavona. In the Oman Sea, one site (Dibba) had an outbreak of black band disease (BBD) on Pavona $(21.1 \%)$. 
Fig. 2 Canonical analysis of principal coordinates (CAP) ordination quantifying the relative similarity in coral community structure across three regions of the Arabian Peninsula ( $n=17$ sites). The closer the sites are in multivariate space, the more similar their coral communities are, with those coral genera exerting the strongest influence on spatial variations in community structure overlaid as a bi-plot (the length of the vector is proportional to the strength of the correlation). Squared canonical correlations equal 0.937 and 0.746 for CAP1 and CAP2, respectively

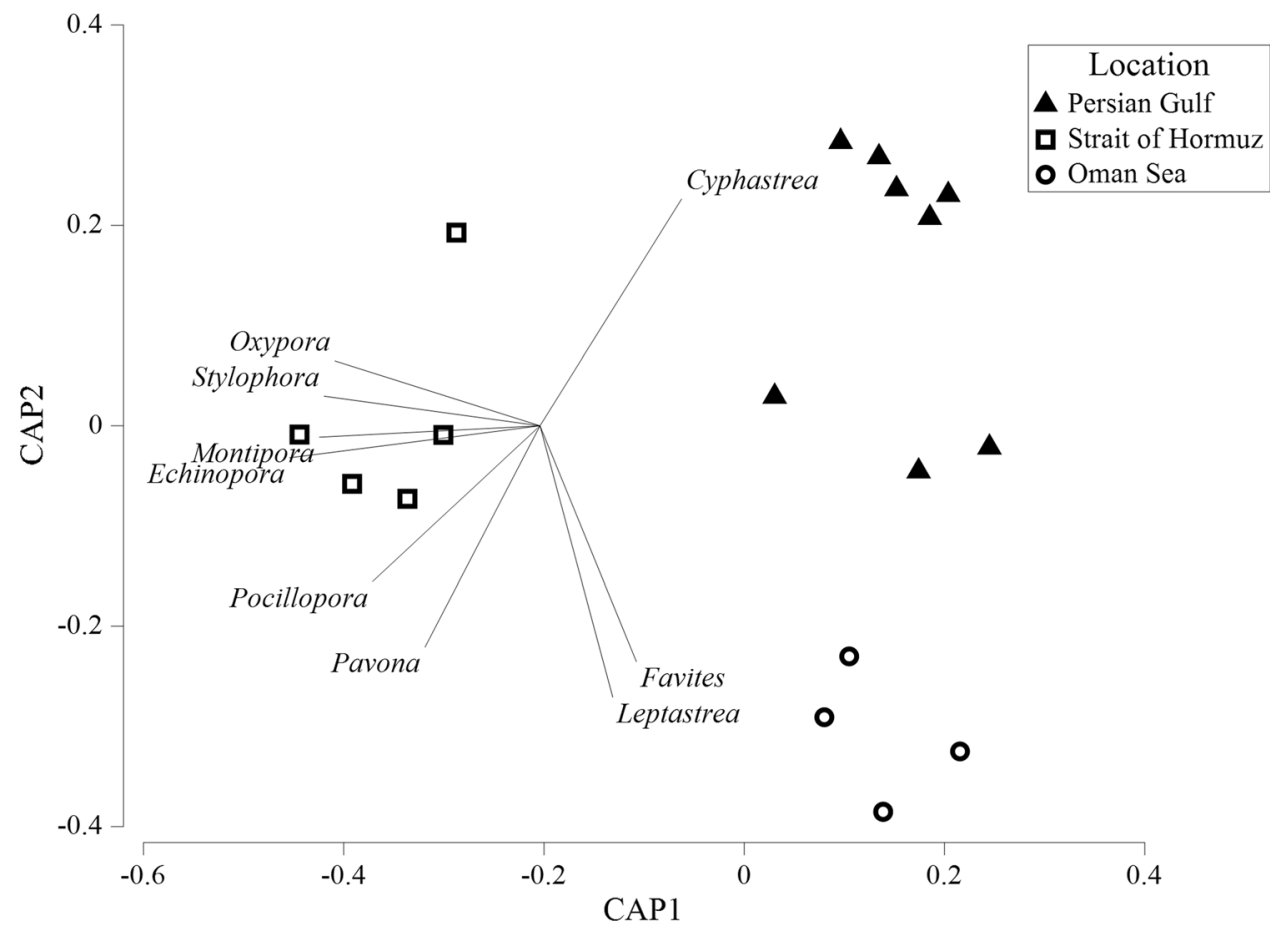

\section{Differences in disease prevalence among coral genera and regions}

Twenty-five coral genera were found within survey transects, but only seven showed signs of disease. Disease prevalence differed among the coral genera within each ocean region (Persian Gulf $X^{2}=261.4$, df $=6, p<0.01$; Strait of Hormuz $X^{2}=58.4$, df $=8, p<0.01$; and Oman Sea $X^{2}=276$, df $\left.=7, p<0.01\right)$. Coral genera that were affected more commonly than expected based on their abundance in the community included Acropora and Platygyra at sites within the Persian Gulf, Echinopora, Pavona, Platygyra and Porites at sites within the Strait of Hormuz and Pavona at sites within the Oman Sea (Fig. 6). Consistent among all three regions, coral genera that showed less disease than expected (disease resistant) included Cyphastrea and Faviidae (Favites and Dipsastraea) (Fig. 6).

\section{Disease-environment associations}

Of all the possible models containing unique combinations of the eight predictor variables, the optimal model, for predicting spatial variation in disease prevalence, explained $82.2 \%$ of the variability across sites and contained three predictors: range in mean annual sea surface temperature $(59.4 \%$ of the variation), organic pollution $(13.6 \%)$ and proximity to shore $(9.1 \%)$ (Table 6). A positive relationship was found between disease prevalence and each of the three predictors (Fig. 7). However, it should be noted that the positive relationship between disease prevalence and organic pollution is skewed by a single site (Saadiyat) so that relationship is less clear. Disease assemblage patterns were best explained by two predictors: range in mean annual sea surface temperature $(27.9 \%$ of the variability) and proximity to shore $(21.1 \%)$. These two variables explained $49.0 \%$ of the overall variation in disease assemblages across sites (Table 6).

\section{Discussion}

We surveyed 17 reefs along the northeastern Arabian coast and found high coral cover (40 to 65\%) and diversity (25 coral genera). Thirteen diseases were found affecting seven coral genera present within transects. Diseases included tissue loss diseases of unknown etiology (white syndromes) in six genera, black band disease in five genera, growth anomalies in three genera and yellow-banded tissue loss (Arabic yellow band) in one genus.

\section{Common and unique diseases impact Arabian corals}

Tissue loss disease has been reported in a number of coral genera from the Persian Gulf (Riegl 2002; Riegl et al. 2012; Alidoost Salimi et al. 2017) and from Oman Sea (Coles 1994), but our study extends the list of affected genera to include Cyphastrea and Goniopora. Tissue loss is a common manifestation of disease in corals and has been found worldwide either affecting a single coral genus or 
Fig. 3 Representative photos of coral diseases found during surveys at sites within the Persian Gulf, Strait of Hormuz and Oman Sea. a Porites yellow-banded tissue loss, b Porites white syndrome, c Porites growth anomaly, d Porites bleached patch, e Platygyra white syndrome, f Platygyra growth anomaly
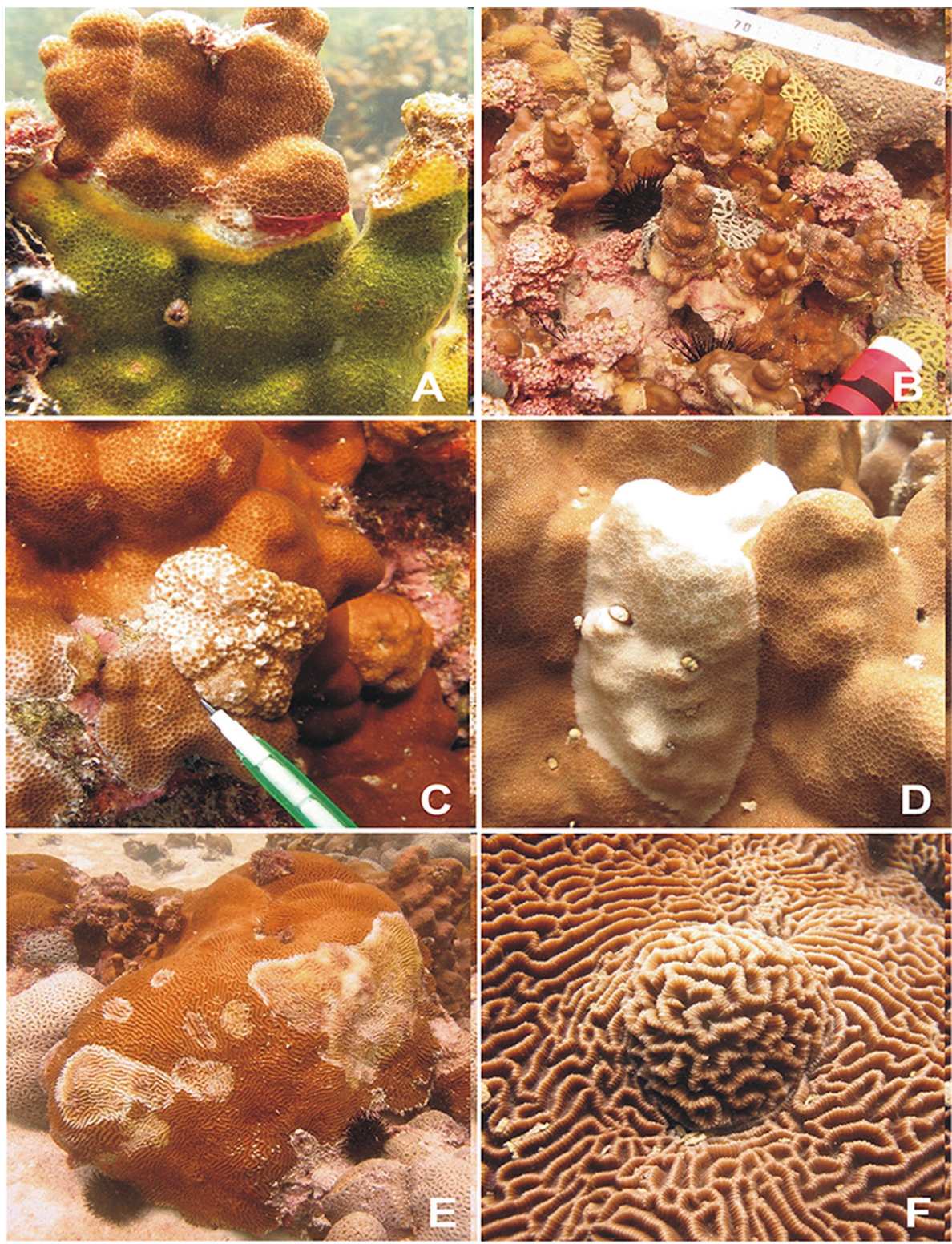

species at a site (Raymundo et al. 2005; Williams and Miller 2005; Aeby et al. 2011b; Williams et al. 2011b) or affecting multiple coral genera (Willis et al. 2004; Precht et al. 2016). The underlying etiologies of tissue loss diseases differ with multiple bacterial pathogens implicated (Patterson et al. 2002; Sussman et al. 2008; Ushijima et al. 2012, 2014, 2016; Beurmann et al. 2017), chimeric parasites (Work et al. 2011) as well as a variety of other organisms (Work et al. 2012). Tissue loss lesions in a single coral species can also have different etiologies. For example, three different pathogenic bacterial species can cause tissue loss disease in the reef coral, Montipora capitata, in Kaneohe Bay, Oahu. The pathogen, Vibrio owensii, creates chronic tissue loss lesions (Ushijima et al. 2012), and both Vibrio coralliilyticus and
Pseudoalteromonas piratica produce acute tissue loss lesions, but under different environmental conditions (Ushijima et al. 2014; Beurmann et al. 2017). As such, we consider tissue loss diseases in this region as non-specific host responses to a variety of agents.

Bleached patches and growth anomalies on corals along the Arabian Peninsula present biogeographic range extensions for both types of lesions. Bleached patches have been reported in multiple coral genera (Lawrence et al. 2014; Aeby et al.2015), and while their etiologies are unknown, viruses have been implicated for Porites on the Great Barrier Reef (Lawrence et al. 2014). Growth anomalies have also been reported in multiple coral genera from other regions (Sutherland et al. 2004) and Acropora from Oman (Coles and Seapy 1998), but this is the first report of 

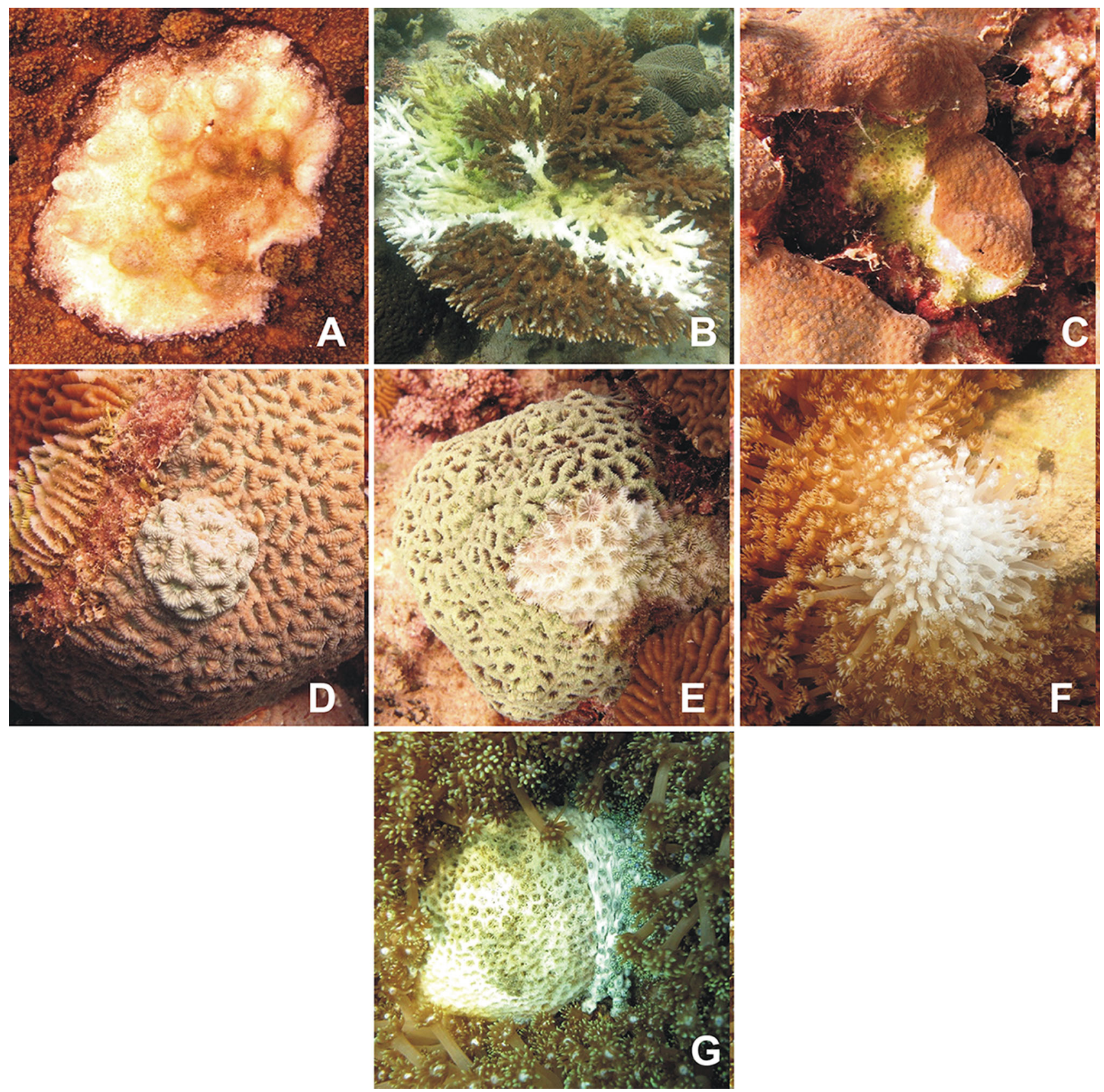

Fig. 4 Representative photographs of coral diseases found during surveys at sites within the Persian Gulf, Strait of Hormuz and Oman Sea. a Black band disease on Acropora, b Acropora white syndrome,

growth anomalies in Porites, Platygyra and Faviidae (Favites and Dipsastraea) in this region. Growth anomalies in Porites are widespread across the Indo-Pacific (Aeby et al. 2011c), but there are limited reports of growth anomalies in Faviidae (Sutherland et al. 2004) and only two reports of growth anomalies in Platygyra: one from the Great Barrier Reef (Loya et al. 1984) and one from New Caledonia (Aeby et al. 2015). c Cyphastrea white syndrome, d Faviidae (Dipsastraea) growth anomaly, e Faviidae (Dipsastraea) white syndrome, f Goniopora bleached patch, g Goniopora white syndrome

The one disease that appears to be unique to the Persian Gulf is Porites yellow-banded tissue loss. This disease presents with subacute progressive tissue loss, but the area between denuded skeleton and healthy tissue is a yellow mucus band as opposed to a bare, white skeleton as found with typical white syndromes. Similar disease signs on Porites and other coral genera have been reported in the Persian Gulf and were termed Arabic yellow-banded disease (Riegl 2002; Riegl et al. 2012) and Porites peeling 
Fig. 5 Differences in average disease prevalence (\%) among three regions surveyed along the Arabian Peninsula in August 2016. Data reflect mean and standard error
Table 4 Frequency of occurrence (FOC) of different coral diseases within three ocean regions surveyed along the Arabian Peninsula in August 2016

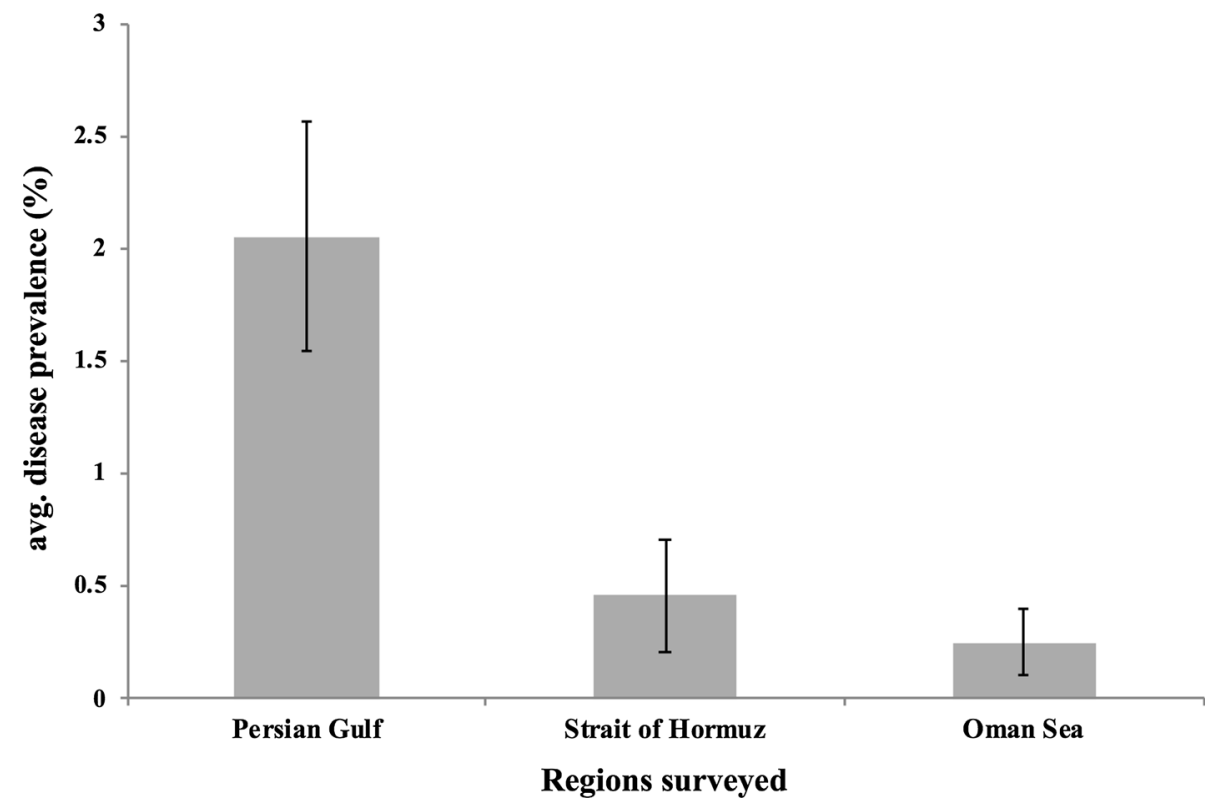

\begin{tabular}{|c|c|c|c|c|}
\hline Coral taxa & Lesion type & $\begin{array}{l}\text { Persian } \\
\text { gulf }\end{array}$ & $\begin{array}{l}\text { Strait of } \\
\text { hormuz }\end{array}$ & $\begin{array}{l}\text { Oman } \\
\text { sea }\end{array}$ \\
\hline \multirow[t]{4}{*}{ Porites } & YBTL & 50 & 20 & 0 \\
\hline & WS & 62.5 & 0 & 0 \\
\hline & GA & 0 & 40 & 25 \\
\hline & Bl patch & 25 & 40 & 50 \\
\hline \multirow[t]{3}{*}{ Platygyra } & WS & 50 & 0 & 0 \\
\hline & GA & 62.5 & 40 & 50 \\
\hline & BBD & 25 & 0 & 0 \\
\hline \multirow[t]{3}{*}{ Favia } & GA & 37.5 & 0 & 0 \\
\hline & WS & 12.5 & 0 & 0 \\
\hline & BBD & 0 & 20 & 0 \\
\hline Cyphastrea & WS & 50 & 0 & 0 \\
\hline \multirow[t]{2}{*}{ Acropora } & WS & 50 & 60 & 5 \\
\hline & $\mathrm{BBD}$ & 0 & 0 & 5 \\
\hline Echinopora & BBD & 0 & 40 & 0 \\
\hline Pavona & BBD & 0 & 40 & 2 \\
\hline \multirow[t]{2}{*}{ Goniopora } & Bl patch & 0 & 0 & 25 \\
\hline & WS & 0 & 20 & 0 \\
\hline
\end{tabular}

FOC represents the proportion of total surveys $(\%)$ which contained corals affected by each particular disease. Eight sites were surveyed in the Persian Gulf, 5 sites in the Strait of Hormuz and 4 sites in the Oman Sea. The most common disease in each region in bold. YBTL = yellow-banded tissue loss, $\mathrm{WS}=$ white syndrome, $\mathrm{GA}=$ growth anomaly, $\mathrm{Bl}$ patch = bleached patches, $\mathrm{BBD}=$ black band disease. FOC may differ from prevalence, as FOC includes diseased colonies near, but not within the belt transects. Faviidae includes Favites and Dipsastraea which are difficult to distinguish in the field tissue loss (Alidoost Salimi et al. 2017), which distinguishes them from the standard 'white syndrome' classification. Under the dissecting microscope, the yellow band was found to be overlying bare skeleton and was composed of a viscous material with zooxanthellae present, suggesting the yellow band is derived from coral tissue. In the field, we also frequently observed red filamentous cyanobacteria in the region between the yellow band and healthy tissue. It is not known what role, if any, the cyanobacteria play in the disease process, but the lesion appearance and the ecology of the disease presented very differently than black band disease. 
Table 5 Average prevalence $(\%)$ of different coral diseases within three regions surveyed along the Arabian Peninsula in August, 2016

\begin{tabular}{lllll}
\hline Coral taxa & Lesion type & Persian gulf & Strait of hormuz & Oman sea \\
\hline Porites & YBTL & $1.14(0.84)$ & $0.08(0.08)$ & 0 \\
& WS & $0.57(0.29)$ & 0 & 0 \\
& GA & 0 & $0.26(0.21)$ & $0.05(0.05)$ \\
& Bl patch & $0.08(0.06)$ & $0.12(0.08)$ & $0.05(0.05)$ \\
Platygyra & WS & $1.58(1.26)$ & 0 & 0 \\
& GA & $0.52(0.26)$ & $1.15(0.84)$ & 0 \\
Favia & GA & $0.09(0.08)$ & 0 & 0 \\
Cyphastrea & WS & $0.02(0.02)$ & 0 & $0.08(0.08)$ \\
Acropora & WS & $0.51(0.23)$ & 0 & 0 \\
Echinopora & WS & $2.5(1.14)$ & $0.38(0.25)$ & $0.26(0.26)$ \\
Pavona & BBD & 0 & $2.75(1.72)$ & 0 \\
\hline
\end{tabular}

Eight sites were surveyed in the Persian Gulf, 5 sites in the Strait of Hormuz and 4 sites in the Oman Sea. YBTL = yellow-banded tissue loss, WS = white syndrome, GA = growth anomaly, Bl patch = bleached patches, BBD = black band disease. Parentheses indicate SEM. Faviidae includes Favites and Dipsastraea which are difficult to distinguish in the field
Some diseases were widespread such as Platygyra growth anomalies, Porites bleached patches and Acropora white syndrome, which were found in all three regions examined. Other diseases had a smaller geographic spread such as Porites white syndrome found only at sites in the Persian Gulf, Porites yellow-banded tissue loss which was found mainly in the Persian Gulf with one site in the Strait of Hormuz and Porites growth anomalies which occurred exclusively in the Strait of Hormuz and Oman Sea. Although Porites is a common coral in all three regions, the types of lesions that developed on Porites in these regions differ (e.g., growth anomalies in Strait of Hormuz and Oman Sea versus tissue loss lesions in the Persian Gulf). The emergence of coral disease occurs from a complex interplay between the host, causative agent and environment (Work and Aeby 2006), and so, it is not surprising that the environmental conditions occurring within the different regions are facilitating the development of different types of diseases. Environmental conditions are a known component affecting coral health (Harvell et al. 2007) and this has been found in numerous studies. For example, Porites is a common coral genus across the IndoPacific, but the prevalence of growth anomalies in this genus is strongly associated with human presence (Aeby et al. 2011c).

\section{Taxonomic variation in disease susceptibility}

Corals possess constituent immunity that contribute to their capacity to resist disease, and investment in immunity differs among coral taxa resulting in certain species or families being more susceptible to disease than others (Palmer et al. 2010). Consistent differences in disease susceptibility across families or species have been found in numerous regions (Willis et al. 2004; Aeby et al. 2008, 2011b; Vargas-Ángel 2009), and we also found differences in disease prevalence among coral genera with only seven out of 25 genera within transects showing any signs of disease. Coral genera within our surveys with higher disease prevalence than expected based on their abundance in the field (higher disease susceptibility) included Acropora, Pavona, Platygyra and Echinopora. Acropora is reported as especially vulnerable to disease in many regions of the Pacific (Willis et al. 2004; Aeby et al. 2008; Vargas-Ángel 2009; Myers and Raymundo 2009; Page et al. 2009; Haapkylä et al. 2009; Aeby et al. 2011c; Weil et al. 2012), Indian Ocean (Thinesh et al. 2011; Montano et al. 2012) as well as the Western Atlantic (Santavy et al. 2001; Porter et al. 2001). Reports of localized outbreaks of disease in Acropora have also been reported from across the Pacific (Willis et al. 2004; Aeby 2005; Aeby et al. 2011b; Williams et al. 2011a), and disease has almost extirpated acroporids from Florida and some regions in the Caribbean (Gladfelter 1982; Aronson and Precht 2001; Patterson et al. 2002). Our study confirms that Acropora within the Persian Gulf are also vulnerable to diseases.

Discovering relatively high disease prevalence in Pavona, Platygyra and Echinopora is unusual and is in contrast to the low disease levels usually found in these genera in other regions (Aeby et al. 2008; Myers and Raymundo 2009; Vargas-Ángel 2009; Thinesh et al. 2011; Montano et al. 2012; Aeby et al. 2015). However, in our study Echinopora and Pavona were both affected exclusively by black band disease (BBD). Black band disease affects numerous coral genera worldwide and is more 
Fig. 6 Relationship between overall abundance of coral genera within transects and overall proportion of corals with disease signs (lesions) along the Arabian Peninsula. Top graph shows data (all surveys combined) from the Persian Gulf, middle graph from Strait of Hormuz and bottom graph from Oman Sea. Faviidae includes Favites and Dipsastraea

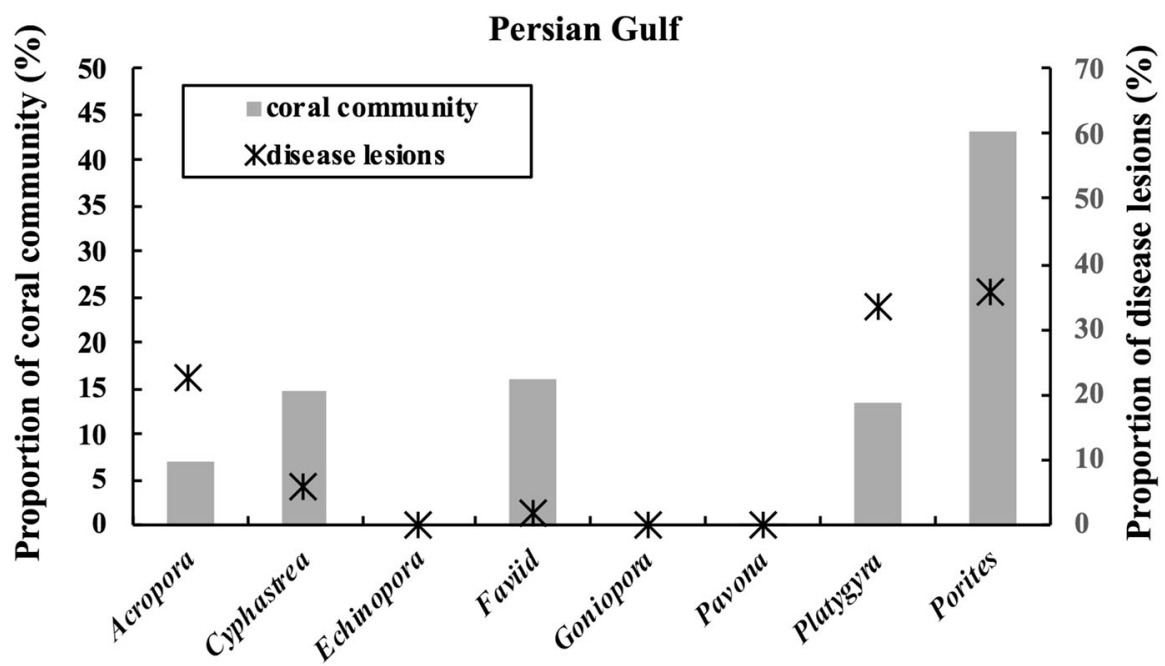

\section{Coral genera}

Strait of Hormuz

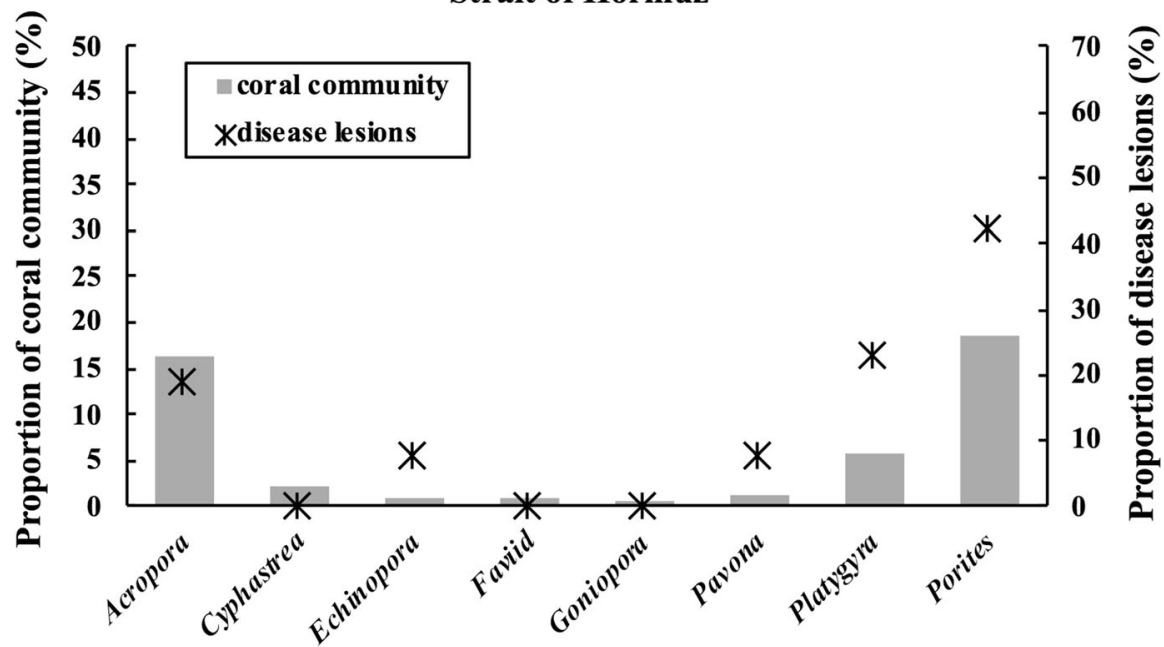

Coral genera

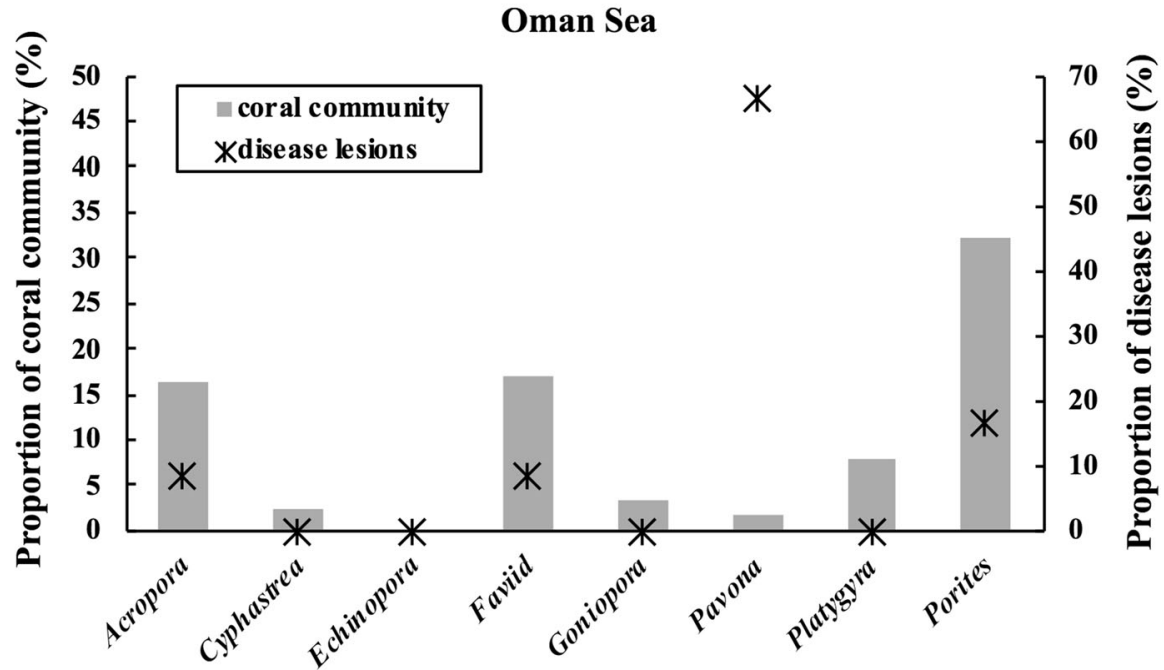

Coral genera 
Table 6 Distance-based permutational multiple regression analyses (DISTLM) relating overall disease prevalence and disease assemblages to eight predictor variables (depth, coral cover, organic pollution, ocean pollution, distance to shore, degree heating weeks and average range of SST)

\begin{tabular}{|c|c|c|c|}
\hline Response variable & Candidate model & $\mathrm{AICc}$ & $\begin{array}{l}\% \text { variability } \\
\text { explained }\end{array}$ \\
\hline \multirow[t]{4}{*}{ Overall disease prevalence } & Organic + near_dist + SST_range & -3.152 & 82.2 \\
\hline & Ocean_poll + organic + near_dist + SST_range & -2.522 & 87.0 \\
\hline & Ocean_poll + organic + SST_range & -2.366 & 81.1 \\
\hline & dhw + organic + SST_range & -2.006 & 80.7 \\
\hline \multirow[t]{4}{*}{ Disease assemblages } & Near_dist + SST_range & 103.8 & 49.0 \\
\hline & SST_range & 105.3 & 27.9 \\
\hline & Depth + near_dist + SST_range & 106.1 & 54.9 \\
\hline & Ocean_poll + near_dist + SST_range & 106.5 & 53.8 \\
\hline
\end{tabular}

Organic $=$ organic pollution, near_dist $=$ distance to shore, SST_range $=$ average range of SST, ocean_poll $=$ ocean pollution, dhw $=$ degree heating weeks. The top four combinations of the eight predictors are shown, with the 'penalty' for increasing model complexity in relation to model performance (\% variation explained) identified using Akaike's information criterion with a second-order bias correction applied (AICc)

common during the summer months (Sutherland et al. 2004) which is when we surveyed the reefs. So, it may be more accurate to say these two genera were more susceptible to BBD than other coral genera, but not necessarily to disease in general, consistent with other studies. In contrast, Platygyra was affected by BBD, growth anomalies and white syndromes and high disease levels in this coral genus may represent a difference in disease susceptibility in corals along the northeastern Arabian coast as compared to other regions. However, there are many areas across the world that lack baseline disease surveys and that need to be addressed before potential differences in disease susceptibility among coral genera can be understood.

\section{Regional patterns in coral disease prevalence are characterized by a high frequency of localized outbreaks}

Our study found an overall prevalence of $1.1 \%$ which is within the range reported for other regions. Disease prevalence of less than $1 \%$ has been reported (Aeby et al. 2008, 2015; Haapkylä et al. 2009; Vargas-Ángel 2009) as well as over 7\% (Willis et al. 2004; Weil et al. 2012). Disease prevalence clearly varies between regions and points to the importance of developing an understanding of what 'normal' disease levels are for your local reefs. Having baseline disease data and building disease assessment into monitoring programs will give managers the capacity to recognize and respond quickly to any changes in disease levels. Although we lack historical information on disease levels in this region, compared to baseline field surveys in other regions (Willis et al. 2004; Aeby et al. 2008; Haapkylä et al. 2009; Williams et al. 2011b; VargasÁngel 2009), we found a high number of localized outbreaks of specific diseases with almost half of our total survey sites having outbreak levels of disease. Disease is a natural component of all populations, but disease outbreaks indicate a shift in the host-pathogen-environment triad of disease causation. Temperature stress has been associated with a number of disease outbreaks (Miller et al. 2009; Bruno et al. 2007; Brandt and McManus 2009), and our field surveys were conducted in August, corresponding to peak summer temperatures in the region and that might, in part, help explain the high number of outbreaks. Three of our sites had BBD outbreaks and two sites had white syndrome outbreaks, two diseases which are known to occur more commonly in the warmer summer months (Kuta and Richardson 1996; Willis et al. 2004; Bruno et al. 2007; Sato et al. 2009; Williams et al. 2011a). Alternatively, perhaps localized disease outbreaks regularly occur on reefs in these regions due to other environmental stressors. Longer-term disease studies, including surveys during different seasons, are needed to understand disease dynamics on northeastern Arabian coral reefs.

\section{Persian Gulf corals are particularly vulnerable to coral disease impacts}

Coral reefs within the Persian Gulf have to contend with large fluctuations in ocean temperatures and salinities, leading to a lower diversity of coral species (John et al. 1990; Vaughan and Al-Mansoori 2019). However, many coral species live under these challenging environmental conditions and their ability to tolerate extreme temperatures has been linked to thermal adaptations by both the corals and their photosynthetic symbiotic algae (Howells et al. 2016a; Smith et al. 2017; Kirk et al. 2018). Although Persian Gulf corals may be able to tolerate high ocean 
Fig. 7 Scattergrams with trend lines showing the relationship between disease prevalence and a mean annual SST range, b modeled organic pollution, and c proximity to shore. These three variables make up the optimal model explaining spatial variation in disease prevalence at survey sites within the Persian Gulf, Strait of Hormuz and Oman Sea
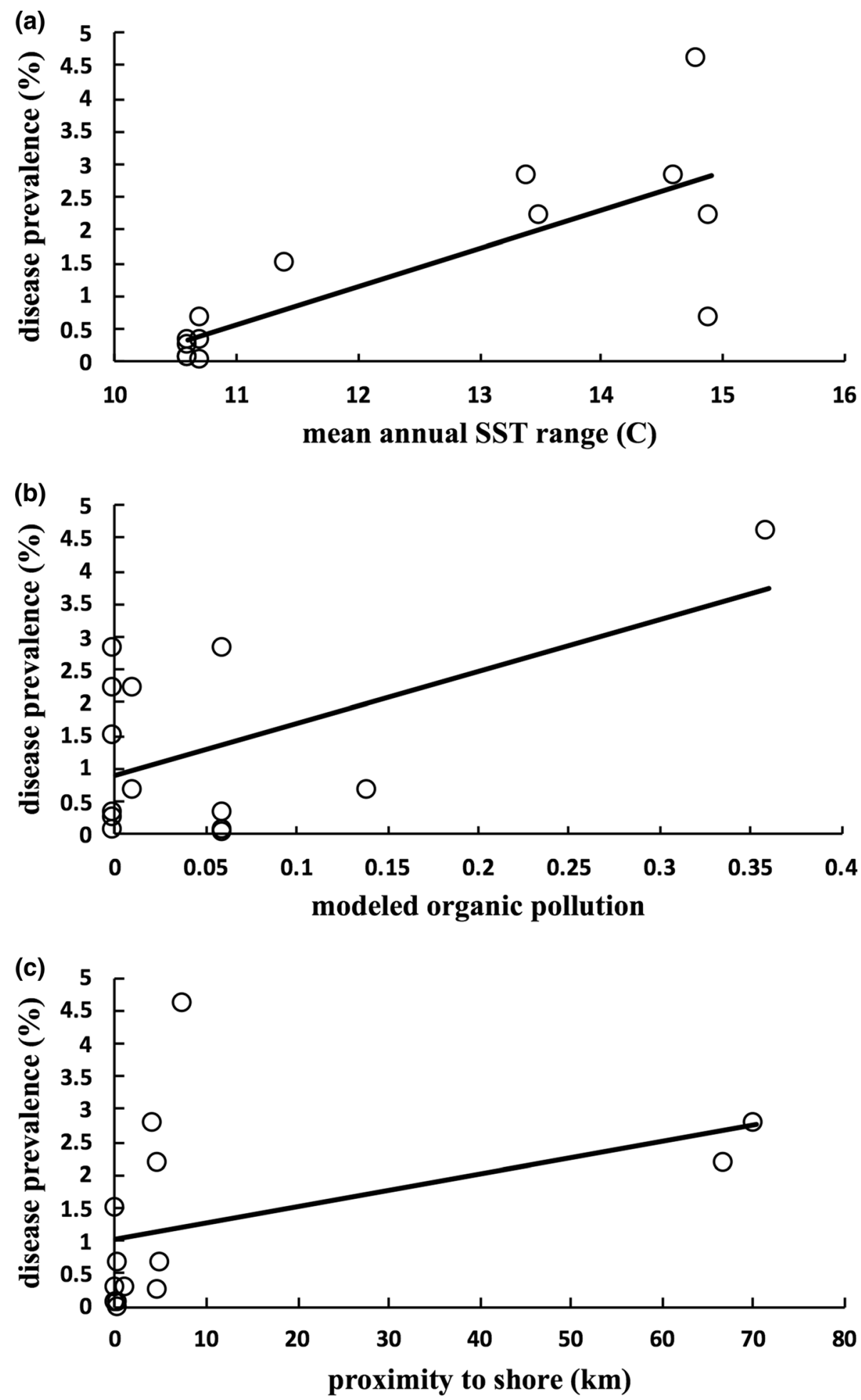

temperatures, our findings of a high number of outbreaks on coral reefs within the southern Persian Gulf suggest that their abilities to fight diseases may be compromised. For some coral species, hosting thermally tolerant symbiont taxa comes at a cost such as reduced growth (Little 2004; Jones and Berkelmans 2010), lipid stores and egg sizes
(Jones and Berkelmans 2011) or increased disease susceptibility (Stat et al. 2008; Rouzé et al. 2016). ShoreMaggio et al. (2018) found that for the reef coral, Montipora capitata, in Hawaii, the trade-off for corals was between disease and bleaching susceptibility. Coral colonies hosting the thermally tolerant variants of Durusdinium 
were more susceptible to tissue loss diseases compared to colonies hosting Cladocopium symbionts. It is possible that similar trade-offs between bleaching resistance and disease susceptibility are occurring in some Persian Gulf coral species and further research in this area would be of interest.

Conversely, perhaps the higher disease levels found in Persian Gulf corals are a result of chronic poor environmental conditions. Chronic temperature and salinity stress both exert significant energetic costs on corals, with reduced growth, reproduction and survivorship the outcome (Coles and Jokiel 1992; Porter et al. 1999). Corals in the southern Persian Gulf are also exposed to significant sedimentation (Riegl et al. 2012) which negatively affects coral health (Fabricius 2005). The energetic costs of chronic multiple environmental stressors do not come without trade-offs. Bauman et al. (2013) found that the size structure of coral populations in the southern Persian Gulf (Dubai and Abu Dhabi) was significantly smaller and their size structured skewed compared to conspecifics in the Strait of Hormuz (Musandam). Additionally, Howells et al. (2016b, 2018) found that Persian Gulf corals tend to have lower rates of calcification and fecundity compared to conspecifics in the Gulf of Oman. Corals also mount an immune response when faced with environmental challenges which can be energetically costly (Palmer 2018). In laboratory experiments, Sheridan et al. (2014) found that acute exposure to sterile sediments induced a significant immune response in the reef coral, M. patula, and resulted in a reduction in storage lipids. In addition to chronic challenges, coral reefs within the southern Persian Gulf also experienced major bleaching events in 1996, 1998, 2002, 2010, 2012 and 2017 (Riegl 1999, 2002; Riegl et al. 2011; Burt et al. 2019). Bleaching events results in direct mortality and short- and long-term negative effects on growth and reproduction (Baird and Marshall 2002; Mendes and Woodley 2002; Howells et al. 2016b) and higher susceptibility to tissue loss diseases (Miller et al. 2009; Mydlarz et al. 2009; Heron et al. 2010; Muller et al. 2018). For corals in the Persian Gulf, energy depletion resulting from repeated bleaching events and chronic multiple stressors could result in a weakening of the immune system, reducing the capacity of corals to resist infections and thus help explain the higher disease prevalence we found in this region.

Corals in the Persian Gulf live in an extreme environment which has led to some interesting adaptations and findings about how corals respond to thermal stress (Burt et al. 2014; Vaughan and Burt 2016). Thermal stress not only causes bleaching, but it is known to drive a variety of coral diseases, and thus, this region provides a platform to study disease at the edge of corals' thermal range. Our study provides an important baseline of information on diseases that occur in this region, but much more research is needed to understand how corals and their pathogens interact under these extreme conditions. This may provide critical insights into the future of coral reefs facing the continued impacts of human stressors and global climate change.

Acknowledgements Open Access funding provided by the Qatar National Library. This project was supported by the National Geographic Society grant \#977015. Fieldwork and sample collection permissions were provided by the Environment Agency Abu Dhabi, Fujairah Municipality and Dibba Municipality, and the Musandam Governorate. Fieldwork was undertaken with the NYUAD Core Research Vessel, the Palms Dive Center, Al Mahara Dive Center and Extra Divers Musandam. We thank Dain McParland and Grace Vaughan at NYUAD for logistical assistance. The manuscript was improved by comments from two anonymous reviewers.

On behalf of all authors, the corresponding author states that there is no conflict of interest.

Open Access This article is licensed under a Creative Commons Attribution 4.0 International License, which permits use, sharing, adaptation, distribution and reproduction in any medium or format, as long as you give appropriate credit to the original author(s) and the source, provide a link to the Creative Commons licence, and indicate if changes were made. The images or other third party material in this article are included in the article's Creative Commons licence, unless indicated otherwise in a credit line to the material. If material is not included in the article's Creative Commons licence and your intended use is not permitted by statutory regulation or exceeds the permitted use, you will need to obtain permission directly from the copyright holder. To view a copy of this licence, visit http://creativecommons. org/licenses/by/4.0/.

\section{References}

Aeby GS (2005) Outbreak of coral disease in the Northwestern Hawaiian Islands. Coral Reefs 24:481

Aeby G, Work T, Fenner D, Didonato E (2008) Coral and crustose coralline algae disease on the reefs of American Samoa. In: Proceedings of the 11th international coral reef symposium, vol 7, pp 197-201

Aeby GS, Williams GJ, Franklin EC, Kenyon J, Cox EF, Coles S, Work TM (2011a) Patterns of coral disease across the Hawaiian Archipelago: relating disease to environment. PLoS ONE 6:e20370

Aeby GS, Bourne DG, Wilson B, Work TM (2011b) Coral diversity and the severity of disease outbreaks: across-regional comparison of Acropora white syndrome in a species-rich region (American Samoa) with a species-poor region (Northwestern Hawaiian Islands). J Mar Biol 2011:1-8

Aeby GS, Williams GJ, Franklin EC, Haapkyla J, Harvell CD, Neale S, Page CA, Raymundo L, Vargas-Ángel B, Willis BL, Work TM, Davy SK (2011c) Growth Anomalies on the coral genera Acropora and Porites are strongly associated with host density and human population size across the Indo-Pacific. PLoS ONE 6:e16887

Aeby G, Tribollet A, Lasne G, Work T (2015) Assessing threats from coral and crustose coralline algae disease on the reefs of New Caledonia. Mar Freshwater Res 67:455-465

Aeby G, Callahan S, Cox E, Runyon C, Smith A, Stanton F, Ushijima B, Work T (2016) Emerging coral diseases in Kāne'ohe Bay, 
O'ahu, Hawai'i (USA): two major disease outbreaks of acute Montipora white syndrome. Dis Aquat Org 119:189-198

Akaike H (1973) Maximum likelihood identification of Gaussian autoregressive moving average models. Biometrika 60:255-265

Alidoost Salimi M, Mostafavi P, Fatemi S, Aeby G (2017) Health status of corals surrounding Kish Island, Persian Gulf. Dis Aquat Org 124:77-84

Anderson MJ (2001) A new method for non-parametric multivariate analysis of variance. Austral Ecol 26:32-46

Anderson MJ, Willis TJ (2003) Canonical analysis of principal coordinates: a useful method of constrained ordination for ecology. Ecology 84:511-525

Aronson RB, Precht WF (2001) White-band disease and the changing face of Caribbean coral reefs. In: Porter JW (ed) The ecology and etiology of newly emerging marine diseases. Springer, Dordrecht, pp 25-38

Baird A, Marshall P (2002) Mortality, growth and reproduction in scleractinian corals following bleaching on the Great Barrier Reef. Mar Ecol Prog Ser 237:133-141

Bauman AG, Pratchett MS, Baird AH, Riegl B, Heron SF, Feary DA (2013) Variation in the size structure of corals is related to environmental extremes in the Persian Gulf. Mar Environ Res 84:43-50

Beurmann S, Ushijima B, Videau P, Svoboda CM, Smith AM, Rivers OS, Aeby GS, Callahan SM (2017) Pseudoalteromonas piratica strain OCNO03 is a coral pathogen that causes a switch from chronic to acute Montipora white syndrome in Montipora capitata. PLoS ONE 12:e0188319

Brandt ME, McManus JW (2009) Disease incidence is related to bleaching extent in reef-building corals. Ecology 90:2859-2867

Bruno JF, Selig ER (2007) Regional decline of coral cover in the Indo-Pacific: timing, extent, and subregional comparisons. PLoS ONE 2:e711

Bruno JF, Selig ER, Casey KS, Page CA, Willis BL, Harvell CD, Sweatman H, Melendy AM (2007) Thermal stress and coral cover as drivers of coral disease outbreaks. PLoS Biol 5:e124

Burnham KP, Anderson DR (2004) Multimodel inference: understanding AIC and BIC in model selection. Sociol Methods Res 33:261-304

Burt JA (2014) The environmental costs of coastal urbanization in the Arabian Gulf. City 18:760-770

Burt J, van Lavieren H, Feary D (2014) Persian Gulf reefs: an important asset for climate science in urgent need of protection. Ocean Challenge 20:49-56

Burt J, Paparella F, Al-Mansoori N, Al-Mansoori A, Al-Jailani H (2019) Causes and consequences of the 2017 coral bleaching event in the southern Persian/Arabian Gulf. Coral Reefs 38:567-589

Claereboudt MR (2019) Oman. In: World seas: an environmental evaluation. Elsevier, pp 25-47

Clarke KR, Somerfield PJ, Chapman MG (2006) On resemblance measures for ecological studies, including taxonomic dissimilarities and a zero-adjusted Bray-Curtis coefficient for denuded assemblages. J Exp Mar Biol Ecol 330:55-80

Coles SL (1994) Extensive coral disease outbreak at Fahl Island, Gulf of Oman, Indian Ocean. Coral Reefs 13:242

Coles SL (2003) Coral species diversity and environmental factors in the Arabian Gulf and the Gulf of Oman: a comparison to the Indo-Pacific region. Atoll Res Bull 507:1-19

Coles SL, Jokiel P (1992) Effects of salinity on coral reefs. In: Connell D, Hawker D (eds) Pollution in tropical aquatic systems. CRC Press, Boca Raton, pp 147-166

Coles SL, Seapy DG (1998) Ultra-violet absorbing compounds and tumorous growths on acroporid corals from Bandar Khayran, Gulf of Oman, Indian Ocean. Coral Reefs 17:195-198
Death G, Fabricius K, Sweatman H, Puotinen M (2012) The 27-yr decline of coral cover on the Great Barrier Reef and its causes. Proc Natl Acad Sci 109:17995-17999

Fabricius KE (2005) Effects of terrestrial runoff on the ecology of corals and coral reefs: review and synthesis. Mar Pollut Bull 50:125-146

Gardner T, Cote I, Gill J, Grant A, Watkinson A (2003) Long-term region-wide declines in Caribbean corals. Science 301:958-960

Gladfelter W (1982) White-band disease in Acropora palmata: implications for the structure and growth of shallow reefs. Bull Mar Sci 32:639-643

Haapkylä J, Unsworth R, Seymour A, Melbourne-Thomas J, Flavell M, Willis B, Smith D (2009) Spatio-temporal coral disease dynamics in the Wakatobi Marine National Park, South-East Sulawesi, Indonesia. Dis Aquat Org 87:105-115

Halpern B, Frazier M, Potapenko J, Casey K, Koenig K (2015) Cumulative human impacts: raw stressor data. Knowl Netw Biocomplex. https://doi.org/10.5063/f1s180fs

Harvell CD, Jordan-Dahlgren E, Merkel S, Rosenberg E, Raymundo L, Smith G, Weil E, Willis B (2007) Coral disease, environmental drivers and the balance between coral and microbial associates. Oceanography 20:172-195

Heron SF, Willis B, Skirving W, Eakin M, Page C, Miller I (2010) Summer hot snaps and winter conditions: modelling white syndrome outbreaks on Great Barrier Reef corals. PLoS ONE 5:e12210. https://doi.org/10.1371/journal.pone.0012210

Hicks CC, Cohen PJ, Graham NA, Nash KL, Allison EH, D'Lima C, Mills DJ, Roscher M, Thilsted SH, Thorne-Lyman AL, MacNeil MA (2019) Harnessing global fisheries to tackle micronutrient deficiencies. Nature 574(7776):95-98

Howells E, Abrego D, Meyer E, Kirk N (2016a) Host adaptation and unexpected symbiont partners enable reef-building corals to tolerate extreme temperatures. Global Change Biol 22:1. https:// doi.org/10.1111/gcb. 13250

Howells E, Ketchum R, Bauman A, Mustafa Y, Watkins K, Burt J (2016b) Species-specific trends in the reproductive output of corals across environmental gradients and bleaching histories. Mar Poll Bull 105(2):532-539

Howells E, Dunshea G, McParland D, Vaughan G, Heron S, Pratchett M, Burt J, Bauman A (2018) Species-specific coral calcification responses to the extreme environment of the southern Persian Gulf. Front Mar Sci 5:56. https://doi.org/10.3389/fmars.2018. 00056

Hughes TP, Barnes ML, Bellwood DR, Cinner JE, Cumming GS, Jackson JBC, Kleypas J, van de Leemput IA, Lough JM, Morrison TH, Palumbi SR, van Nes EH, Scheffer M (2017) Coral reefs in the Anthropocene. Nature 546:82-90

Hughes TP, Graham NAJ, Jackson JBC, Mumby PJ, Steneck RS (2010) Rising to the challenge of sustaining coral reef resilience. Trends Ecol Evol 25:633-642

Hurvich CM, Tsai CL (1989) Regression and time series model selection in small samples. Biometrika 76:297-307

Jackson JBC, Donovan MK, Cramer KL, Lam VV (eds) (2014) Status and trends of Caribbean coral reefs: 1970-2012. Global coral reef monitoring network. IUCN, Gland

John VC, Coles SL, Abozed AI (1990) Seasonal cycles of temperature, salinity and water masses of the western Arabian Gulf. Oceanol Acta 13:273-281

Jones A, Berkelmans R (2010) Potential costs of acclimatization to a warmer climate: growth of a reef coral with heat tolerant versus sensitive symbiont types. PLoS ONE 5:e10437

Jones AM, Berkelmans R (2011) Tradeoffs to thermal acclimation: energetics and reproduction of a reef coral with heat tolerant Symbiodinium type-D. J Mar Biol 2011:1-12

Kirk NL, Howells EJ, Abrego D, Burt JA, Meyer E (2018) Genomic and transcriptomic signals of thermal tolerance in heat-tolerant 
corals (Platygyra daedalea) of the Arabian/Persian Gulf. Mol Ecol 27:5180-5194

Kuta KG, Richardson LL (1996) Abundance and distribution of black band disease on coral reefs in the northern Florida keys. Coral Reefs 15:219-223

Lawrence SA, Davy JE, Wilson WH, Hoegh-Guldberg O, Davy SK (2014) Porites white patch syndrome: associated viruses and disease physiology. Coral Reefs 34:249-257

Little AF (2004) Flexibility in algal endosymbioses shapes growth in reef corals. Science 304:1492-1494

Loya Y, Bull G, Pichon M (1984) Tumor formations in scleractinian corals. Helgol Meeresunters 37:99-112

McArdle B, Anderson M (2001) Filling multivariate models to community data: a comment on distance-based redundancy analysis. Ecology 82:290-297

Mendes J, Woodley J (2002) Effect of the 1995-1996 bleaching event on polyp tissue depth, growth, reproduction and skeletal band formation in Montastraea annularis. Mar Ecol Prog Ser 235:93-102

Miller J, Muller E, Rogers C, Waara R, Atkinson A, Whelan KRT, Patterson M, Witcher B (2009) Coral disease following massive bleaching in 2005 causes $60 \%$ decline in coral cover on reefs in the US Virgin Islands. Coral Reefs 28:925-937

Montano S, Strona G, Seveso D, Galli P (2012) First report of coral diseases in the Republic of Maldives. Dis Aquat Org 101:159-165

Muller E, Bartels E, Baums I (2018) Bleaching causes loss of disease resistance within the threatened coral species Acropora cervicornis. eLife 7:e35066

Mydlarz L, Couch C, Weil E, Smith G, Harvell C (2009) Immune defenses of healthy, bleached and diseased Montastraea faveolata during a natural bleaching event. Dis Aquat Org 87:67-78

Myers R, Raymundo L (2009) Coral disease in Micronesian reefs: a link between disease prevalence and host abundance. Dis Aquat Org 87:97-104

Page C, Baker D, Harvell C, Golbuu Y, Raymundo L, Neale S, Rosell K, Rypien K, Andras J, Willis B (2009) Influence of marine reserves on coral disease prevalence. Dis Aquat Org 87:135-150

Palmer C, Bythell J, Willis B (2010) Levels of immunity parameters underpin bleaching and disease susceptibility of reef corals. FESEB J 24:1935-1946

Palmer C (2018) Immunity and the coral crisis. Commun Biol 1:91. https://doi.org/10.1038/s42003-018-0097-4

Pandolfi JM (2003) Global trajectories of the long-term decline of coral reef ecosystems. Science 301:955-958

Pandolfi JM, Connolly SR, Marshall DJ, Cohen AL (2011) Projecting coral reef futures under global warming and ocean acidification. Science 333:418-422

Patterson KL, Porter JW, Ritchie KB, Polson SW, Mueller E, Peters EC, Santavy DL, Smith GW (2002) The etiology of white pox, a lethal disease of the Caribbean elkhorn coral, Acropora palmata. Proc Natl Acad Sci 99:8725-8730

Porter J, Lewis S, Porter K (1999) The effect of multiple stressors on the Florida Keys coral reef ecosystem: a landscape hypothesis and physiological test. Limnol Oceanogr 44:941-949

Porter JW, Dustan P, Jaap WC, Patterson KL, Kosmynin V, Meier OW, Patterson ME, Parsons M (2001) Patterns of spread of coral disease in the Florida Keys. In: Porter JW (ed) The ecology and etiology of newly emerging marine diseases. Springer, Dordrecht, pp 1-24

Pous SP, Carton X, Lazure P (2004) Hydrology and circulation in the Strait of Hormuz and the Gulf of Oman-results from the GOGP99 experiment: 2, Gulf of Oman. J Geophys Res 109:C12038
Precht WF, Gintert BE, Robbart ML, Fura R, van Woesik R (2016) Unprecedented disease-related coral mortality in southeastern Florida. Sci Rep 6:31374

Raymundo L, Rosell K, Reboton C, Kaczmarsky L (2005) Coral diseases on Philippine reefs: genus Porites is a dominant host. Dis Aquat Organ 64:181-191

Riegl B (1999) Coral communities in a non-reef setting in the southern Arabian Gulf (Dubai, UAE): fauna and community structure in response to recurrent mass mortality. Coral Reefs 18:63-73

Riegl B (2002) Effects of the 1996 and 1998 positive sea-surface temperature anomalies on corals, coral diseases and fish in the Arabian Gulf (Dubai, UAE). Mar Biol 140:29-40

Riegl BM, Bruckner AW, Samimi-Namin K, Purkis SJ (2012) Diseases, harmful algae blooms (HABs) and their effects on gulf coral populations and communities. In: Riegl BM, Purkis SJ (eds) Coral reefs of the Gulf. Springer, Dordrecht, pp 107-125

Riegl BM, Purkis SJ, Al-Cibahy AS, Abdel-Moati MA, HoeghGuldberg O (2011) Present limits to heat-adaptability in corals and population-level responses to climate extremes. PLoS ONE 6:e24802

Rouzé H, Lecellier G, Saulnier D, Berteaux-Lecellier V (2016) Symbiodinium clades A and D differentially predispose Acropora cytherea to disease and Vibrio spp. colonization. Ecol Evol 6:560-572

Santavy D, Mueller E, Peters E, MacLaughlin L, Porter J, Patterson K, Campbell J (2001) Quantitative assessment of coral diseases in the Florida keys: strategy and methodology. In: The ecology and etiology of newly emerging marine diseases. Springer, pp 39-52

Sato Y, Bourne DG, Willis BL (2009) Dynamics of seasonal outbreaks of black band disease in an assemblage of Montipora species at Pelorus Island (Great Barrier Reef, Australia). Proc R Soc B Biol Sci 276:2795-2803

Sheppard C (1993) Physical environment of the Gulf relevant to marine pollution: an overview. Mar Pollut Bull 27:3-8

Sheppard C, Al-Husiani M, Al-Jamali F, Al-Yamani F, Baldwin R, Bishop J, Benzoni F, Dutrieux E, Dulvy NK, Durvasula SRV, Jones DA, Loughland R, Medio D, Nithyanandan M, Pilling GM, Polikarpov I, Price ARG, Purkis S, Riegl B, Saburova M, Namin KS, Taylor O, Wilson S, Zainal K (2010) The Gulf: A young sea in decline. Mar Pollut Bull 60:13-38

Sheridan C, Grosjean P, Leblud J, Palmer C, Kushmaro A, Eeckhaut A (2014) Sedimentation rapidly induces an immune response and depletes energy stores in a hard coral. Coral Reefs 33:1067-1076

Shore-Maggio A, Callahan SM, Aeby GS (2018) Trade-offs in disease and bleaching susceptibility among two color morphs of the Hawaiian reef coral, Montipora capitata. Coral Reefs 37:507-517

Smith EG, Hume BCC, Delaney P, Wiedenmann J, Burt JA (2017) Genetic structure of coral-Symbiodinium symbioses on the world's warmest reefs. PLoS ONE 12:e0180169

Stat M, Morris E, Gates RD (2008) Functional diversity in coraldinoflagellate symbiosis. Proc Natl Acad Sci 105:9256-9261

Sussman M, Willis BL, Victor S, Bourne DG (2008) Coral pathogens identified for white syndrome (WS) epizootics in the IndoPacific. PLoS ONE 3:14

Sutherland K, Porter J, Torres C (2004) Disease and immunity in Caribbean and Indo-Pacific zooxanthellate corals. Mar Ecol Prog Ser 266:273-302

Thinesh T, Mathews G, Edward JKP (2011) Coral disease prevalence in the Palk Bay, Southeastern India-with special emphasis to black band. Indian J Geo-Mar Sci 40:813-820 
Ushijima B, Smith A, Aeby GS, Callahan SM (2012) Vibrio owensii induces the tissue loss disease Montipora white syndrome in the Hawaiian reef coral Montipora capitata. PLoS ONE 7:e46717

Ushijima B, Videau P, Burger AH, Shore-Maggio A, Runyon CM, Sudek M, Aeby GS, Callahan SM (2014) Vibrio coralliilyticus strain OCN008 Is an etiological agent of acute Montipora white syndrome. Appl Environ Microbiol 80:2102-2109

Ushijima B, Videau P, Poscablo D, Stengel JW, Beurmann S, Burger AH, Aeby GS, Callahan SM (2016) Mutation of the toxR or $m s h A$ genes from Vibrio coralliilyticus strain OCN014 reduces infection of the coral Acropora cytherea: virulence genes in Vibrio coralliilyticus. Environ Microbiol 18:4055-4067

Vargas-Ángel B (2009) Coral health and disease assessment in the US Pacific remote island areas. Bull Mar Sci 84:211-227

Vaughan GO, Burt JA (2016) The changing dynamics of coral reef science in Arabia. Mar Pollut Bull 105:441-458

Vaughan G, Al-Mansoori Burt J (2019) The Arabian gulf. World seas: an environmental evaluation, 2nd edn. Elsevier, Amsterdam, pp 1-23

Weil E, Irikawa A, Casareto B, Suzuki Y (2012) Extended geographic distribution of several Indo-Pacific coral reef diseases. Dis Aquat Org 98:163-170

Williams D, Miller M (2005) Coral disease outbreak: pattern, prevalence and transmission in Acropora cervicornis. Mar Ecol Prog Ser 301:119-128

Williams GJ, Aeby GS, Cowie ROM, Davy SK (2010) Predictive modeling of coral disease distribution within a reef system. PLoS ONE 5:e9264
Williams GJ, Knapp IS, Work TM, Conklin EJ (2011a) Outbreak of Acropora white syndrome following a mild bleaching event at Palmyra Atoll, Northern Line Islands, Central Pacific. Coral Reefs 30:621

Williams G, Knapp I, Aeby G, Davy S (2011b) Spatial and temporal patterns of scleractinian coral, soft coral, and zoanthid disease on a remote, near-pristine coral reef (Palmyra Atoll, central Pacific). Dis Aquat Org 94:89-100

Williams GJ, Graham NAJ, Jouffray J-B, Norström AV, Nyström M, Gove JM, Heenan A, Wedding LM (2019) Coral reef ecology in the Anthropocene. Funct Ecol 33:1014-1022

Willis BL, Page CA, Dinsdale EA (2004) Coral disease on the Great Barrier Reef. In: Rosenberg E, Loya Y (eds) Coral health and disease. Springer, Berlin, pp 69-104

Work T, Aeby G (2006) Systematically describing gross lesions in corals. Dis Aquat Org 70:155-160

Work TM, Forsman ZH, Szabó Z, Lewis TD, Aeby GS, Toonen RJ (2011) Inter-specific coral chimerism: genetically distinct multicellular structures associated with tissue loss in Montipora capitata. PLoS ONE 6:e22869

Work TM, Russell R, Aeby GS (2012) Tissue loss (white syndrome) in the coral Montipora capitata is a dynamic disease with multiple host responses and potential causes. Proc R Soc B Biol Sci 279:4334-4341

Publisher's Note Springer Nature remains neutral with regard to jurisdictional claims in published maps and institutional affiliations. 